\title{
PERBEDAAN PENINGKATAN HASIL BELAJAR FISIKA SISWA MENGGUNAKAN MODEL PEMBELAJARAN THINK TALK WRITE DENGAN MODEL PEMBELAJARAN TIME TOKEN
}

\section{DIFFERENCES IN IMPROVING STUDENT PHYSICAL LEARNING OUTCOMES USING THINK TALK WRITE LEARNING MODEL WITH TIME TOKEN LEARNING MODEL}

\author{
Darmawan Harefa ${ }^{1^{*}}$ \\ ${ }^{1}$ Dosen Pendidikan Matematika dan Ilmu Pengetahuan Alam STKIP Nias Selatan \\ *Email: harefadarmawan@gmail.com
}

Diterima: 04 Juni 2020. Disetujui: 25 Juli 2020. Dipublikasikan: 10 Agustus 2020

\begin{abstract}
Abstrak: Tujuan dari penelitian ini adalah untuk mengetahui perbedaan peningkatan hasil belajar fisika siswa menggunakan model pembelajaran Think Talk Write dengan model pembelajaran Time Token, penlitian ini menggunakan pendekatan kuantitatif dengan metode quasi eksperimen. Populasi dalam penelitian ini yaitu seluruh siswa kelas VII SMP Negeri 2 Fanayama. Sampel penelitian ini adalah kelas VII-A dengan jumlah siswa 22 orang dan kelas VII-B dengan jumlah siswa 24 orang. Instrumen yang digunakan adalah, tes hasil belajar yang terbagi atas dua yaitu tes awal dan tes akhir. Berdasarkan hasil pengolahan data yang telah dilaksanakan dan perhitungan uji hipotesis diperoleh nilai $\mathrm{t}_{\text {hitung }}=2,898>\mathrm{t}_{\text {tabel }}=1,68$, maka Ho ditolak dan Ha diterima dapat disimpulkan bahwa ada perbedaan peningkatan hasil belajar siswa menggunakan model pembelajaran Think Talk Write dengan model pembelajaran Time Token maka hasil dari itu model pembelajaran Think Talk Write lebih diunggulkan karena model pembelajaran ini dapat mendorong siswa dalam menumbuh kembangkan kemampuan untuk memahami materi fisika yang diajarkan dan kemudian menuliskan inti-inti dari materi tersebut sehingga siswa dapat merumuskan pengetahuan yang didapat dalam bahasanya sendiri dibanding dengan model pembelajaran Time Token.
\end{abstract}

Kata Kunci : Peningkatan, hasil belajar fisika, pembelajaran think talk write, time token

Abstract: This research used a quantitative approach with a quasi-experimental method. The population this study all VII grade students SMP Negeri 2 Fanayama. The sample of this is study was class VII-A with a total of 22 students and class VII-B with a total of 24 students. The instrument used was a test of learning outcomes divided into two, namely the initial test and the final test. Based on the results of data processing that had been carried out and the calculation of the hypothesis test obtained $t_{\text {count }}=2.898>t_{\text {table }}=1.68$, then Ho was rejected and Ha was accepted it can be concluded that there was a difference in the improvement of student learning outcomes using the Think Talk Write (TTW) learning model with the Time learning model Token then the showed results the Think Talk Write (TTW) learning model showed revealed that are more favored because this learning model can encourage students to develop and increase the abilityto understand the physics material being taught and then write down the core of the material so that students can formulate the knowledge acquired in the language itself compared to the Time Token learning model.

Keywords : Improvement, physics learning outcomes, learning of think talk write, time tokens

\section{PENDAHULUAN}

Interaksi antara guru dengan siswa sebagai makna utama dalam proses pembelajaran memegang peranan penting untuk mencapai tujuan pembelajaran yang efektif. Mengingat kedudukan siswa sebagai subjek dan sekaligus juga sebagai objek dalam pembelajaran, maka inti proses pembelajaran adalah kegiatan belajar siswa dalam mencapai tujuan pembelajaran. Hanya saja, kondisi kehidupan yang lebih baik dengan berbagai sarana dan fasilitas cenderung menjadikan anak Indonesia kurang termotivasi untuk belajar, yang akhirnya membawa dampak negatif bagi prestasi belajarnya [1]

Model pembelajaran adalah suatu perencanaan atau pola yang digunakan sebagai pola atau pedoman dalam merencanakan pembelajaran dalam tutorial dan dalam menentukan suatu perangkat. Untuk mencapai tujuan pembelajaran tersebut guru dituntut berperan serta secara aktif, kreatif dan inovatif dalam melakukan pembelajaran agar siswa lebih mudah memahami materi yang disampaikan dan antusias dalam mengikuti proses belajar mengajar, sehingga pembelajaran yang dilakukan berkualitas dan hasil belajar yang dicapai siswa memuaskan [2]. Untuk meningkatkan kemampuan mengajarnya, seorang guru juga dituntut melakukan perubahan dalam cara mengajarnya terutama dalam pembelajaran fisika. Pelajaran asyik dan menyenangkan juga dapat diberikan kepada siswa supaya tertarik dalam belajar [3].

Model pembelajaran pada hakikatnya merupakan suatu pendekatan pembelajaran yang memungkinkan peserta didik, baik secara individu maupun kelompok aktif mencari, menggali, dan menemukan konsep serta prinsip secara holistik dan 
otentik. Pembelajaran memiliki hakikat perencanaan atau perancangan (desain) sebagai upaya untuk membelajarkan siswa [4].

Model pembelajaran Think Talk Write (TTW) merupakan suatu model pembelajaran untuk melatih keterampilan peserta didik dalam menulis. Think Talk Write (TTW) menekankan perlunya peserta didik mengomunikasikan hasil pemikirannya. Aktivitas yang dapat dilakukan untuk menumbuhkembangkan kemampuan pemahaman konsep dan komunikasi peserta didik adalah dengan penerapan pembelajaran Think Talk Write (TTW) [6].

Think Talk Write (TTW) adalah strategi yang memfasilitasi latihan berbahasa secara lisan dan menulis bahasa tersebut dengan lancar ini didasarkan pada pemahaman bahwa belajar adalah sebuah perilaku sosial. Model pembelajaran Think Talk Write (TTW) mendorong siswa untuk brpikir berbicara dan kemudian menuliskan suatu topik tertentu. Model pembelajaran ini digunakan untuk mengembangkan tulisan dengan lancar dan melatih bahasa sebelum dituliskan [5]

Model pembelajaran Think Talk Write dikembangkan oleh Huinker dan Laugghlin [8] "yang dibangun melalui berpikir, berbicara dan menulis". Berdasarkan beberapa definisi di atas, peneliti menyimpulkan bahwa model pembelajaran Think Talk Write adalah model pembelajaran yang mampu mendorong siswa untuk berpikir dan berkomunikasi dan menulis sesuai dengan bahasanya sendiri dan pada tulisan itu siswa menghubungkan ide-ide yang diperolehnya.

Proses pembelajaran memiliki hakikat perencanaan atau perancangan sebagai upaya untuk membelajarakan siswa tidak hanya berinteraksi dengan guru tetapi juga juga dengan siswa yang lain nya di ruangan kelas tersebut [6], maka dari itu model pembelajaran perlu di berikan kepada siswa dalam proses belajar dan mengajar. Menurut pendapat [10] mengemukkan maksud dari model pembelajaran adalah kerangka konseptual dan prosedur yang sistematik dalam mengorganisasikan pengalaman belajar untuk mencapai tujuan belajar tertentu.

Model Pembelajaran Time Token adalah salah satu tipe pembelajaran kooperatif. Siswa dibentuk dalam kelompok belajar, yang dalam pembelajaran ini mengajarkan keterampilan sosial untuk menghindari siswa mendominasi pembincaraan atau menghindarkan siswa diam sama sekali dalam berdiskusi. Guru memberikan materi pembelajaran dan selanjutnya siswa bekerja dalam kelompok masing-masing untuk memastikan semua anggota kelompok telah menguasai materi pembelajaran yang diberikan. Kemudian, siswa melaksanakan tes atas materi yang diberikan dan mereka harus mengerjakan sendiri tanpa bantuan siswa lainnya [6].

Struktur yang dapat yang dapat digunakan untuk mengajarkan keterampilan sosial, untuk menghindari peserta didik mendominasi pembicaraan atau peerta didik diam sama sekali, maka langkah yang efektif adalah dengan menggunakan model pembelajaran Time Token. Sebab, dengan ada pengaturan berbicara dan pemberian kesempatan untuk berbicara keapada masing-masing siswa akan mewujudkan keteraturan siswa untuk berbicara atau mengemukakan pendapat.

Dengan demikian model pembelajaran ini digunakan dalam rangkat meningkatkan kemampuan siswa untuk berbicara kepada orang lain atau dilingkungan umum, sehingga ia memiliki skill atau kemampuan untuk mengemukakan pendapatnya kepada orang banyak [9]. Model pembelajaran menurut [7] adalah pendekatan berpikir dan berbasis masalah, dalam pendekatan ini, siswa diharapkan mampu memiliki beberapa kompetensi sebagai berikut. membuat keputusana) meneliti, b) mengemukakan pendapat, c) menerapkan pengetahuan sebelumnya, d) memunculkan ide-ide, e) membuat keputusan-keputusan, f) mengorganisasi ide-ide, g) membuat hubungan-hubungan.

Model pembelajaran Time Token merupakan salah satu contoh kecil dari penerapan pembelajaran demokratis di lingkungan sekolah. Proses pembelajaran yang demokratis adalah proses belajar yang menempatkan siswa sebagai subjek. Sepanjang proses belajar aktivitas siswa menjadi titik perhatian utama. Dengan kata lain mereka selalu dilibatkan secara aktif. Guru berperan mengajak siswa mencari solusi bersama terhadap permasalahan yang ditemui [7]. Pembelajaran Time Token digunakan untuk melatih dan mengembangkan keterampilan sosial agar siswa tidak mendominasi pembicaraan".

Berdasarkan beberapa definisi di atas, peneliti menyimpulkan bahwa model pembelajaran ini merupakan model pembelajaran yang melibatkan siswa untuk berperan aktif dalam kelompok dan mereka harus mengerjakan sendiri tanpa bantuan siswa lain dalam proses pembelajaran dimana siswa itu sendiri untuk berbicara dan mengemukakan pendapatnya didepan umum. Model pembelajaran Time Token adalah salah satu tipe pembelajaran kooperatif. Siswa dibentuk ke dalam kelompok belajar, yang pembelajaran ini mengajarkan keterampilan sosial untuk menghindari siswa mendominasi pembicaraan atau menghindarkan siswa diam sama sekali dalam berdiskusi. [11]. bahwa aktifitas yang dilakukan siswa selama pembelajaran memungkinkan terjadinya interaksi secara terbuka dan mendorong siswa untuk melakukan hal-hal positif yang menunjang peningkatan akademiknya.

Guru memberikan materi pembelajaran dan selanjutnya siswa bekerja dalam kelompok. Ketika mengerjakan masing-masing soal fisika siswa memastikan semua anggota kelompok telah menguasai materi pembelajaran yang diberikan [13]. Kemudian, siswa melaksanakan tes atas materi yang diberikan dan mereka harus mengerjakan sendiri tanpa bantuan siswa lainnya [6]. 
Berdasarkan uraian tentang model pembelajaran di atas, secara teoritis mendeskripsikan bahwa pembelajaran dengan menggunakan model pembelajaran Think Talk Write (TTW) dan model pembelajaran Time Token dapat mengikutsertakan siswa secara aktif dalam pembelajaran yang akan mempengaruhi hasil belajar siswa. Peneliti ingin mengetahui perbedaan hasil belajar fisika siswa yang menggunakan model pembelajaran Think Talk Write (TTW) dan model pembelajaran Time Token pada materi sistem pencernaan makanan pada manusia. Karena menurut peneliti dengan adanya perbedaan peningkatan hasil belajar siswa yang menggunakan kedua model pembelajaran tersebut maka dapat menjadi pertimbangan bagi seorang guru fisika dalam memilih model pembelajaran yang lebih baik digunakan dalam pembelajaran fisika yang pada hakikatnya digunakan sebagai dasar untuk memperoleh hasil belajar yang lebih optimal [14].

\section{METODE PENELITIAN}

Penelitian ini dilaksanakan di SMP Negeri 2 Fanayama Kabupaten Nias Selatan Tahun Pembelajaran 2019/2020. Penelitian inidilakukan dengan menggunakan metode quasi eksperimen. Menurut [15] peneliti membagi kelompok penelitian menjadi dua kelompok (kelas), yaitu: kelompok eksperimen I menggunakan model pembelajaran Think Talk Write (TTW) dan kelompok eksperimen II menggunakan model pembelajaran Time Token .

Penggunaan kedua model pembelajaran tersebut bertujuan untuk mengetahui perbedaan hasil belajar siswa dengan menggunakan model pembelajaran Think Talk Write (TTW) dan Time Token. Penelitian ini menggunakan Matching Pretest-Posttest Control Group Design [16] seperti yang tertera di bawah ini.

Tabel 1. Desain Penelitian Kuantitatif

\begin{tabular}{cccc}
\hline Kelas & Tes awal & Perlakuan & Tes akhir \\
\hline$\left(\mathrm{E}_{1}\right)$ & $\mathrm{T}_{1}$ & $\mathrm{X}$ & $\mathrm{T}_{2}$ \\
$\left(\mathrm{E}_{2}\right)$ & $\mathrm{T}_{1}$ & $\mathrm{Y}$ & $\mathrm{T}_{2}$ \\
\hline
\end{tabular}

Keterangan:

$\mathrm{T}_{1}=$ Pemberian tes awal pada kelas eksperimen I dan kelas eksperimen II

$\mathrm{X}_{(\mathrm{E} 1)}=$ Kelas eksperimen I yang diberi perlakuan dengan model pembelajaran Think Talk Write (TTW).

$\mathrm{Y}_{(\mathrm{E} 2)}=$ Kelas eksperimen II yang diberi perlakuan dengan model pembelajaran Time Token.

$\mathrm{T}_{2}=$ Pemberian tes akhir pada kelas eksperimen I dan kelas eksperimen II

\section{HASIL DAN PEMBAHASAN}

Data yang diperoleh peneliti dalam penelitian ini adalah hasil belajar kognitif siswa setelah melaksanakan proses pembelajaran dengan menggunakan Think Talk Write (TTW) di kelas eksperimen I dan model pembelajaran Time Token di kelas eksperimen II.
Kelas Eksperimen I

a) Hasil Pengolahan Data Nilai Tes Awal di kelas eksperimen I. Berdasarkan data di peroleh bahwa ada 1 orang siswa yang memperoleh nilai 55, 5 orang siswa yang memperoleh nilai 55,4 orang siswa yang memperoleh nilai 61,8 orang siswa nilai 68,3 orang siswa nilai 70 , dan 1 orang siswa nilai 75

b) Rata-rata Hitung dan Simpangan Baku. Berdasarkan data hasil tes awal kelas eksperimen I di atas selanjutnya diolah untuk mendapatkan rata-rata hasil belajar dan simpangan baku. Berikut adalah hasil rata-rata nilai hasil tes awal kelas eksperimen I berdasarkan data diatas:

$$
\begin{aligned}
& \sum X_{i}=1479 \\
& \sum X_{i}^{2}=91925 \quad n=24
\end{aligned}
$$

Sehingga diperoleh: $\bar{x}=\frac{\sum X_{i}}{n}=\frac{1479}{24}=61,625$

Simpangan baku

$$
\text { adalah: } S^{2}=\frac{n \sum x_{i}^{2}-\left(\sum x_{i}\right)^{2}}{n(n-1)}=33,983
$$

Kelas Eksperimen II

a) Hasil Pengolahan Data Nilai Tes Awal di kelas eksperimen II. Berdasarkan data pada tabel 4.2 diperoleh bahwa ada 1 orang siswa yang memperoleh nilai 50,3 orang siswa nilai 55,6 orang siswa nilai 60, dan 11 orang siswa nilai 65 .

b) Rata-rata Hitung dan Simpangan Baku. Berdasarkan data hasil tes awal kelas eksperimen II di atas selanjutnya diolah untuk mendapatkan rata-rata hasil belajar dan simpangan baku [14] Berikut adalah hasil rata-rata nilai hasil tes awal kelas eksperimen II berdasarkan data diatas:

$$
\begin{aligned}
& \sum X_{i}=1340 \\
& \sum X_{i}^{2}=82150 \quad n=24
\end{aligned}
$$

Sehingga diperoleh:

$\bar{x}=\frac{\sum X_{i}}{n}=\frac{1340}{22}=60,91$

Simpangan baku adalah:

$$
S^{2}=\frac{n \sum x_{i}^{2}-\left(\sum x_{i}\right)^{2}}{n(n-1)}=\frac{22(82150)-(1340)^{2}}{24(24-1)}
$$$$
s^{2}=25,33, s=\sqrt{25,33}=5,03
$$

\section{Uji Homogenitas}

Setelah kedua sampel pada penelitian telah dihitung rata-rata dan simpangan bakunya, maka selanjutnya menguji homogenitas varians kedua populasi tersebut. [17] Uji homogenitas ini dilakukan untuk mengetahui apakah kedua varians populasi homogen.

Berdasarkan data nilai tes awal hasil belajar siswa, diketahui nilai rata-rata dan standar deviasi hasil belajar siswa sebagai berikut:

Kelas eksperimen I : $\bar{x}=61,625$ dan $\mathrm{S}_{1}{ }^{2}=33,983$

Kelas eksperimen II : $\bar{x}=60,91$ dan $\mathrm{S}_{2}{ }^{2}=25,33$ 
Selanjutnya untuk melakukan pengujian homogenitas, maka nilai tersebut di atas disubsitusikan pada rumus berikut:

$$
\mathrm{F}_{\text {hitung }}=\frac{\text { varians terbesar }}{\text { varians terkcil }}=\frac{33_{,}, 983}{25,33}=11,34
$$

Dari hasil tersebut diketahui bahwa $F_{\text {hitung }}$ sebesar 1,34. Kemudian selanjutnya dikonsultasikan pada $\mathrm{F}_{\text {tabel }}$ untuk dk $\left(\mathrm{n}_{1}-1, \mathrm{n}_{2}-1\right)$ pada taraf signifikan 0,05 diperoleh $\mathrm{dk}=(23,21)$ tidak ada maka kita menggunakan rumus interpolasi dengan menganggap $\mathrm{t}_{(23,21)}$ berada pada interval 20 dan 24 , caranya adalah:

Dari hasil perhitungan tersebut diperoleh $\mathrm{t}_{\text {hitung }}=$ 1,34 dan $t_{\text {tabel }}=2,06$. Ternyata $t_{\text {hitung }}=1,34<t_{\text {tabel }}$ $=2,06$ maka kelas tersebut homogen yang berarti mewakili populasi sebagai sampel penelitian .

Tes Akhir

Kelas Eksperimen I

a) Hasil Pengolahan Data Nilai Tes Akhir di kelas eksperimen I. Berdasarkan data diperoleh bahwa 5 orang siswa memperoleh nilai 70,8 orang siswa nilai 75 , dan 9 orang siswa nilai 80 . seluruh siswa tuntas dalam proses pembelajaran dengan persentase ketuntasan $100 \%$.

b) Rata-rata Hitung dan Simpangan Baku. Berdasarkan data hasil tes akhir kelas eksperimen I di atas selanjutnya diolah untuk mendapatkan rata-rata hasil belajar dan simpangan baku. Berikut adalah hasil rata-rata nilai hasil tes akhir kelas eksperimen berdasarkan data diatas:

$$
\begin{aligned}
& \sum X_{i}=1650 \\
& \sum X_{i}^{2}=135955 \quad n=22
\end{aligned}
$$

Sehingga diperoleh: $\overline{\bar{x}}=\frac{\sum x_{\bar{i}}}{n}=\frac{1650}{22}=75$

Simpangan baku adalah: $S^{2}=\frac{n \sum x_{i}^{n}-\left(\sum x_{i}\right)^{2}}{n(n-1)}$

$S^{2}=19,761$

Kelas Eksperimen II.

a) Hasil Pengolahan Data Nilai Tes Akhir di kelas Eksperimen II. Berdasarkan data diperoleh bahwa ada 5 orang siswa memperoleh nilai yang 60, 2 orang siswa nilai 65,5 orang siswa nilai 70,8 orang siswa nilai 75 , dan 2 orang siswa nilai 80 .

b) Rata-rata Hitung dan Simpangan Baku. Berdasarkan data hasil tes akhir kelas eksperimen II di atas selanjutnya diolah untuk mendapatkan rata-rata hasil belajar dan simpangan baku. Berikut adalah hasil rata-rata nilai hasil tes akhir kelas eksperimen berdasarkan data diatas [16]:

$$
\begin{aligned}
& \sum X_{i}=1540 \\
& \sum X_{i}^{2}=108750 \quad n=22
\end{aligned}
$$

Sehingga diperoleh: $\bar{x}=\frac{\sum x_{\hat{i}}}{n}=\frac{1540}{22}=70$
Simpangan baku adalah:

$$
\begin{aligned}
& S^{2}=\frac{n \sum X_{i}^{2}-\left(\sum x_{i}\right)^{2}}{n(n-1)}= \\
& \frac{22(108750)-(1540)^{2}}{22(22-1)}=45,24, s= \\
& \sqrt{45,24}=6,73
\end{aligned}
$$

\section{Uji Hipotesis}

Berdasarkan perolehan data dari hasil tes hasil penelitian maka diperoleh data :

$\begin{array}{ll}\text { Kelas Eksperimen I } & : \bar{x}=75 \text { dan } \mathrm{S}_{1}{ }^{2}=19,761 \\ \text { Kelas Eksperimen II } & : \bar{x}=70 \text { dan } \mathrm{S}_{2}{ }^{2}=45,24 .\end{array}$

Selanjutnya data tersebut di atas disubsitusikan pada rumus uji $t$, dan sebelumnya terlebih dahulu dihitung nilai S gabungan, sebagai berikut [17]:

Sehingga, varians gabungan:

$$
\begin{aligned}
& S^{2}=\frac{\left(n_{1}-1\right) s_{1}^{2}+\left(n_{2}-1\right) s_{2}^{2}}{n_{1}+n_{2}-2}= \\
& \frac{(22-1) \times 19_{2} 761+(24-1) \times 45,24}{22+24-2}=
\end{aligned}
$$

$\sqrt{33,079}, S=5,75$

Setelah diperoleh nilai $\mathrm{S}$ gabungan, selanjutnya dilakukan perhitungan nilai t hitung:

$$
\begin{aligned}
& \mathrm{t}=\frac{\bar{x}_{1}-\bar{x}_{2}}{s \sqrt{\frac{1}{n_{1}}+\frac{1}{n_{2}}}}=\frac{75-70}{5,75 \times \sqrt{\frac{1}{22}+\frac{1}{24}}}= \\
& \frac{5}{5,75 \times 0,30}=\frac{5}{1,725}=2,898
\end{aligned}
$$

Kemudian dikonsultasikan pada tabel harga $\mathrm{t}$ pada taraf nyata $(\alpha)=0,05$, maka statistik t berdistribusi student dengan $\mathrm{dk}=\left(n_{1}+n_{2}-2\right)$.

Dari hasil perhitungan tersebut diperoleh $\mathrm{t}_{\text {hitung }}=$ 2,898 dan $t_{\text {tabel }}=1,68$. Ternyata nilai $t_{\text {hitung }}=2,898>$ $\mathrm{t}_{\text {tabel }}=1,68$ maka Ho ditolak dan Ha diterima yang berarti: "Ada Perbedaan Hasil Belajar Siswa Menggunakan Model Pembelajaran Think Talk Write (TTW) dengan Model Pembelajaran Time Token pada Sistem Pencernaan di Kelas VII SMP Negeri 2 Fanayama Tahun Pembelajaran 2019/2020”.

\section{Analisis Penerapan Model Pembelajaran Think Talk Write (TTW) Terhadap Hasil Belajar Kognitif Siswa}

Berdasarkan hasil analisis data penelitian pada proses pembelajaran dengan menggunakan model pembelajaran Think Talk Write (TTW) dapat mempengaruhi hasil belajar siswa terutama pada ranah kognitif. Model pembelajaran Think Talk Write (TTW) membantu melatih keterampilan peserta didik dalam mengkomunikasikan hasil pemikiran nya. Melalui penelitian yang dilakukan di SMP Negeri 2 Fanayama memperoleh hasil bahwa dengan menggunakan model pembelajaran Think Talk Write (TTW) diperoleh perubahan pada hasil belajar siswa sebelumnya pada tes awal sebesar 61,62 dan pada tes 
akhir rata-rata hasil belajar siswa mencapai 75 . Hal ini dapat disimpulkan bahwa dengan menggunakan Model Pembelajaran Think Talk Write (TTW) dikategorikan baik, maka siswa dapat lebih kreatif yang mengakibatkan hasil belajar siswa juga meningkat.

\section{Implikasi Model Pembelajaran Think Talk Write (TTW) terhadap Hasil Belajar}

Penerapan model pembelajaran Think Talk Write (TTW) ini mempunyai beberapa implikasi yaitu implikasi terhadap guru, terhadap siswa dan terhadap waktu pembelajaran. Implikasi terhadap guru yaitu guru harus jeli dalam mengkondisikan kelas agar siswa dapat terkontrol dengan mudah dan memiliki kemampuan yang sama serta mampu bekerja sama dalam kelompok, saling menghargai pendapat orang lain, aktif dalam memecahkan masalah yang ada sehingga dapat memahami materi yang disampaikan, serta guru dituntut untuk memiliki wawasan yang luas, memiliki akses informasi tentang materi yang banyak dan mampu memberikan arahan kepada siswa yang sedang bertanya.

Implikasi terhadap siswa yaitu siswa dituntut untuk aktif dalam belajar kelompok, saling bekerjasama, mampu mengemukakan pendapat, memiliki rasa tanggungjawab terhadap hasil kerja kelompok, kemudian siswa ditunntut untuk berpikir kritis dan dapat menguasai materi pembelajaran serta dapat mengajarkannya kepada teman kelompoknya yang belum memahami materi pembelajaran, sedangkan implikasi terhadap waktu pembelajaran yaitu kertebatasan waktu, berdasarkan penelitian yang dilakukan oleh [18] dengan judul Penerapan Model Pembelajaran Kooperatif Tipe Think Talk Write Dilengkapi Time Token Terhadap Kompetensi Fisika Kelas X, Terjadinya peningkatan kompetensi fisika peserta didik dalam proses pembelajaran fisika. Diperlihatkan melalui rerata kompetensi sikap pada kelas eksperimen adalah 83 dan 78,45 pada kelas kontrol. Untuk kompetensi pengetahuan rerata nilai yang diraih peserta didik pada kelas eksperimen adalah 80,41 dan 75,56 yang diraih oleh kelas kontrol. Kemudian rerata kompetensi keterampilan yang didapatkan 84 pada kelas eksperimen dan 81 yang didapat oleh kelas kontrol.

Berdasarkan uraian tersebut dan dari hasil penelitian hal ini juga dapat simpulkan bahwa hasil belajar kognitif siswa pada mata pelajaran fisika dengan menggunakan Model Pembelajaran Think Talk Write (TTW) pada tes akhir rata-rata hasil belajar siswa mencapai 75 berbeda dengan hasil belajar kognitif siswa dengan menggunakan Model Pembelajaran Time Token pada tes akhir rata-rata hasil belajar siswa mencapai 70. Hal ini dapat disimpulkan bahwa Model Pembelajaran Think Talk Write (TTW) lebih unggul dibanding dengan model pembelajaran Time Token di Kelas VII SMP Negeri 2 Fanayama tahun pembelajaran 2019/2020.
Berdasarkan uraian tersebut dan dari hasil penelitian hal ini juga dapat simpulkan bahwa hasil belajar kognitif siswa pada mata pelajaran fisika dengan menggunakan Model Pembelajaran Time Token pada tes akhir rata-rata hasil belajar siswa mencapai 70. Hal ini dapat disimpulkan bahwa Model Pembelajaran Time Token lebih meningkat di Kelas VII SMP Negeri 2 Fanaya Tahun Pembelajaran 2019/2020.

Melalui penelitian dengan menggunakan model pembelajaran Time Token diperoleh perubahan pada hasil belajar siswa sebelumnya pada tes awal sebesar 61,62 dan pada tes akhir rata-rata hasil belajar siswa mencapai 70. Hal ini dapat disimpulkan bahwa dengan menggunakan Model Pembelajaran Time Token dapat mempengaruhi hasil belajar siswa.

\section{Analisis Penerapan Model Pembelajaran Time Token Terhadap Hasil Belajar Kognitif Siswa}

Penerapan model pembelajaran Time Token ini mempunyai beberapa implikasi yaitu implikasi terhadap guru, terhadap siswa dan terhadap waktu pembelajaran. Implikasi terhadap guru yaitu guru harus bisa mengkondisikan kelas dan guru harus berperan aktif untuk mengajak siswa mencari ide-ide baru untuk memecahkan permasalahan yang ditemui.

Implikasi terhadap siswa yaitu siswa dituntut untuk menjadi aktif dalam kegiatan pembelajaran, mendrong meningkatkan inisiatif dan partisipasi, mampu mengemukakan pendapat, menumbuhkan kebiasaan pada siswa untuk saling mendengarkan masukan dari teman-teman yang lain, sedangkan implikasi terhadap waktu pembelajaran yaitu keterbatasan waktu karena pada proses pembelajaran semua siswa harus mendapatkan kupon berbicara. Sejalan dengan penelitian yang dilakukan oleh [19].

Pada kompetensi keterampilan, peneliti menggunakan lembar unjuk kerja untuk memperoleh data. Berdasarkan analisis data, peneliti mendapatkan bahwa nilai rata-rata siswa kelas eksperimen 1 adalah 76,14 dan nilai rata-rata siswa kelas eksperimen 2 adalah 79,29. Artinya, nilai rata-rata siswa kelas eksperimen yang menggunakan LKS berorinetasi model kooperatif tipe TTW lebih tinggi dibandingkan nilai rata-rata siswa kelas eksperimen yang menggunakan LKS berorietansi model kooperatif tipe TAI. Meski begitu, bukan berarti bahwa LKS tipe TTW lebih baik daripada LKS tipe TAI

Berdasarkan uraian tersebut dan dari hasil penelitian hal ini juga dapat simpulkan bahwa hasil belajar kognitif siswa pada mata pelajaran fisika dengan menggunakan Model Pembelajaran Time Token pada tes akhir rata-rata hasil belajar siswa mencapai 70. Hal ini dapat disimpulkan bahwa Model Pembelajaran Time Token lebih meningkat di Kelas VII SMP Negeri 2 Fanayama Tahun Pembelajaran 2019/2020 
Berdasarkan hasil pengolahan data yang telah dilaksanakan dan perhitungan uji hipotesis ternyata nilai $\mathrm{t}_{\text {hitung }}=2,898>\mathrm{t}_{\text {tabel }}=1,68$, maka Ho ditolak dan Ha diterima yang berarti: "Ada Perbedaan Hasil Belajar Siswa Menggunakan Model Pembelajaran Think Talk Write (TTW) dengan Model Pembelajaran Time Token maka dari itu model pembelajaran Think Talk Write (TTW) lebih unggul karena model pembelajaran ini dapat mendorong siswa dalam menstimulus kembangkan kemampuan siswa untuk memahami materi fisika yang diajarkan dan kemudian menuliskan serta inti-inti dari materi sehingga siswa dapat merumuskan pengetahuan yang didapat dalam bahasa nya sendiri dibanding dengan model pembelajaran Time Token. terhadap hasil belajar fisika siswa kelas VII SMP Negeri 2 Fanayama Tahun Pembelajaran 2019/2020.

\section{DAFTAR PUSTAKA}

[1] M. Wena. (2010) Strategi Pembelajaran Inovatif Kontemporer Suatu Tinjauan Konseptual Operasional. Jakarta: Bumi Aksara.

[2] Harefa, D. (2018) "Efektifitas Metode Fisika Gasing Terhadap Hasil Belajar Fisika Ditinjau Dari Atensi Siswa (Eksperimen Pada Siswa Kelas Vii Smp Gita Kirtti 2 Jakarta)," Faktor. Jurnal. Ilmiah kependidikan, vol. 5. (1). 35-48

[3] Trianto. (2014). Model Pembelajaran Terpadu. Jakarta: PT Bumi Aksara.

[4] Atmodiwirjo. (200). Manajemen pendidikan indonesia. Jakarta: Ardaditiya.

[5] Huda. (2014) Model-model Pengajaran dan Pembelajaran. Yogyakarta: Pustaka Pelajar.

[6] Gee, E. (2019) "Kemampuan Pemecahan Masalah Matematika Melalui Alur Belajar Berbasis Realistic Mathematics Education (Rme)," Jurnal Education And Development., vol. 7, no. 3, p. 269.

[7] Majid, A. (2014). Strategi Pembelajaran. Bandung.: PT Remaja Rosdakarya.

[8] Shoimin, A. (2014) "68 Model Pembelajaran Inovatif dalam Kurikulum 2013," Yogyakarta: AR-Ruzz Media.

[9] Istarani. (2012). “58 Model Pembelajaran Inovatif Referensi Guru Dalam Menentukan Model Pembelajaran," Medan.: PT. Media Persada.

[10] A. Zainal. (2013). Model-model, Media, dan Strategi Pembelajaran Kontekstual. (Inovatif). Yogyakarta: Yrama Widya.

[11] M. Kanginan. (2016). IPA Fisika untuk SMP/MTs Kelas VII. Jakarta: Penerbit Erlangga.

[12] D. Harefa. (2017). "Pengaruh Presepsi Siswa Mengenai Kompetensi Pedagogik Guru Dan
Minatbelajar Siswa Terhadap Prestasi Belajar Ilmu Pengetahuan Alam (Survey pada SMK Swasta di Wilayah Jakarta Utara)," Horis. J. Ilmu Pendidik. dan Lingusitik, vol. 7, no. 2, pp. 49-73.

[13] Sukardi (2009) Metodologi Penelitian Pendidikan-Kompetensi dan Praktiknya. Jakarta: Bumi Aksara..

[14] N. Sudjana. (2014). Penelitian Hasil Proses Belajar Mengajar. Bandung.: Remaja Rosdakarya.

[15] Sugiyono. (2012). Metode Penelitian Kuantitatif Kualitatif dan R\&D. Bandung. Alfabeta.

[16] S. Arikunto. (2006). Prosedur Penelitian Suatu Pendekatan Praktek. Jakarta: PT Rineka Cipta,

[17] U..Supardi. (2012). Aplikasi Statistika dalam Penelitian. Jakarta: PT. Ufuk Publishing House.

[18] Imron. (2018). "Penerapan Model Pembelajaran Kooperatif Tipe Think Talk Write Dilengkapi Time Token Terhadap Kompetensi Fisika Kelas X," Pillar Phys. Educ, vol. 11, no. 1, pp. 89-96.

[19] Harefa, D. (2020). Peningkatan Prestasi Rasa Percaya Diri Dan Motivasi Terhadap Kinerja Guru IPA. Media Bina Ilmiah, 13(10), 17731786.

[20] Hidayati. (2019) "Perbedaan Hasil Belajar Fisika Menggunakan Lks Berorientasi Model Pembelajaran Kooperatif Tipe TTW Dengan Tipe TAI Pada Materi Gerak Parabola Dan Gerak Melingkar Pada Siswa Kelas X SMAN 8 Padang." Pillar Phys. Educ. vol. 11, no. 1, pp. 41-48. 